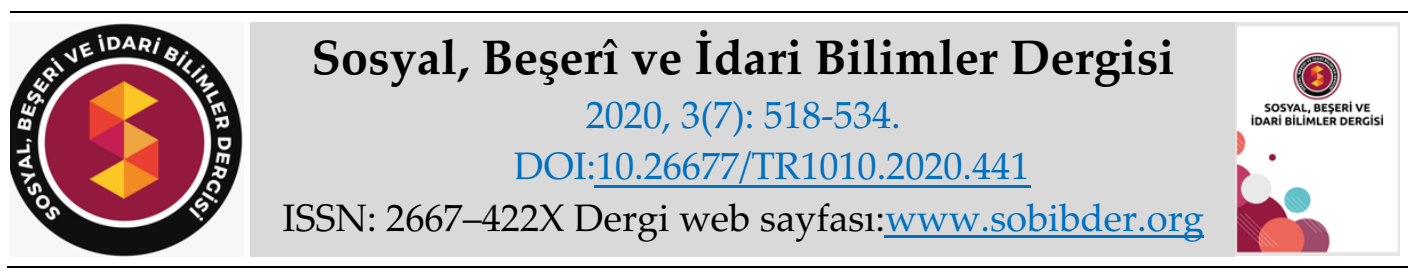

KAVRAMSAL MAKALESI

\title{
Ödemiş İlçesinin (İzmir) Yöresel Yemekler Açısından İncelenmesi
}

Öğr. Gör. Dr. Nükhet Adalet AKPULAT, Ege Üniversitesi, Çeşme Turizm Fakültesi, İzmir, eposta: nakpulat@yahoo.com

ORCID: https://orcid.org/0000-0002-8015-8267

Öz

Deniz, kum, güneşe dayanan klasik turizmin yerini farklı turizm çeşitleri almaya başlamıştır. $\mathrm{Bu}$ turizm çeşitlerinden birisi de gastronomi turizmidir. Son yıllarda özellikle yöresel kültür motiflerine dayanan yiyeceklere olan ilginin önemli derecede arttığı görülmektedir. Önceden ikinci planda yer alan yeme-içme faaliyetleri artık seyahatin temel nedenlerinden birisi haline gelmiştir. Bu araştırmanın amacı, İzmir'in Ödemiş ilçesinin yöresel yemeklerinin belirlenmesi ve gastronomi turizmi potansiyelinin ortaya konmasıdır. Ödemiş'in yöresel yemeklerinin belirlenmesi için doküman taraması yapılmış ve ortaya çıkan yemekler yerel halka sorularak doğrulanmıştır. Araştırma sonucunda Ödemiş'in yöresel yemekler açısından önemli verilere sahip olduğu, bu yemeklerin ön plana çıkarılarak gastronomi turizmine yönelik mevcut talebin arttırılabileceği belirlenmiştir.

Anahtar Kelimeler: Ödemiş, Gastronomi Turizmi, Yöresel Yiyecekler.

Makale Gönderme Tarihi: 23.04.2020

Makale Kabul Tarihi: 02.07.2020

\section{Önerilen Atıf:}

Akpulat, N. A. (2020). Ödemiş İlçesinin (İzmir) Yöresel Yemekler Açısından İncelenmesi, Sosyal, Beşeri ve İdari Bilimler Dergisi, 3(7): 518-534.

(C) 2020 Sosyal, Beşerî ve İdari Bilimler Dergisi. 


\title{
Journal of Social, Humanities and
} Administrative Sciences

2020, 3(7): 518-534. DOI:10.26677/TR1010.2020.441

ISSN: 2667-422X Dergi web sayfası:www.sobibder.org

\section{CONCEPTUAL PAPER}

\section{Examining The Ödemiş County (İzmir) in Terms of Local Dishes}

Dr. Nükhet Adalet AKPULAT, Ege University, Çeşme Tourism Faculty, İzmir, e-mail: nakpulat@yahoo.com

ORCID: https://orcid.org/0000-0002-8015-8267

\begin{abstract}
Different tourism types have started to replace the classic tourism based on sea, sand and sun. One of these tourism types is gastronomy tourism. Recently, the interest in dishes associated with local cultural motifs has increased. Board activities, which were previously in the second plan, have become one of the main reasons for travel. The aim of this study is to determine the local dishes of Ödemiş county of İzmir and to present the potential of gastronomy tourism. Document review was carried out in order to determine the local dishes of Ödemiş and the obtained dishes were confirmed by asking the local residents. According to the results of the study, it was found that Ödemiş has important data in terms of local dishes and that the current demand for gastronomy tourism can be increased by highlighting these dishes.
\end{abstract}

Keywords: Ödemiş, Gastronomy Tourism, Local Foods.

Received: 23.04 .2020

Accepted: 02.07.2020

\section{Suggested Citation:}

Akpulat, N. A. (2020). Examining The Ödemiş County (İzmir) in Terms of Local Dishes, Journal of Social, Humanities and Administrative Sciences, 3(7): 518-534.

(C) 2020 Sosyal, Beşerî ve İdari Bilimler Dergisi. 


\section{Gíriş}

Günümüzde turizm hareketi gerek nitelik gerekse nicelik bakımdan değişime uğramış, bu değişim, kişilerde çevre bilincinin oluşmasına, insanların tüketim alışkanlıklarının değişmesine ve sağlıklı yaşamın ön plana çıkmasına sebep olmuştur. Bunun sonucunda kitle turizminden uzaklaşılarak gürültü ve kirlilikten uzak, insan ilişkilerinin daha sıcak ve yüz yüze olduğu, doğal yapısı bozulmamış kırsal alanlara doğru yönelen alternatif turizm türlerinin ortaya çıkmasına ve beraberinde farklı bölgelerin turizm açısından önemli duruma gelmesine neden olmuştur (Ongun ve Gövdere, 2014). Kırsal yörelerdeki; el sanatları, otantik doku, farklı yaşayış tarzı ve yöresel yiyecekler kırsal turizm içerisinde önemli çekim unsurları olarak yer almaktadır. Özellikle kırsal yörelerdeki yiyecekler gastronomi turizmi ögesidir ve kırsal turizm içerisinden önemli bir yere sahiptir.

Yiyecek-içecek tüketimi başlı başına turizm türü olarak yeni yeni görünmeye başlasa da aslında sürekli turizmin içinde bulunan deneyimlerin en önemli unsurudur. Birçok akademisyen yiyecek içecek kültürünün toplumsal öneminden, gastronominin turizmdeki rolünden ve turistlerin tercihlerini etkileyen, onları heveslendiren bir faktör olduğunu belirtmiştir. Bu yüzden özgün deneyimler yaşatmak, saygınlık ve statü kazandırmak, ürün farklılaştırmak ve destinasyonu diğerlerinden daha çekici kılmak gibi sebeplerle gastronomi bir araç olarak gösterilmektedir. (Kaşlı vd., 2015: 31). Gastronomi turizmi, gelir seviyesi yüksek, entelektüel, 35-55 yaş arası, farklı mutfak kültürlerine sahip destinasyonlara seyahat etmekten hoşlanan, ürünleri üretildikleri yerde tüketmek isteyen, değişik deneyimlere açık, tecrübelerini başka insanlarla paylaşmak isteyen, yüksek harcamalar yapan turistlerin tercih ettiği bir turizm çeşididir. Gastronomi turizmi yıl boyunca gerçekleştirilebilmesi, diğer turizm çeşitleri ile entegre edildiğinde harcama miktarını ve kalış sürelerini artırması, yerel kalkınmaya katkı sağlaması, çevreye duyarlı gelişimi, yöreye özgü, otantik ve taklit edilemeyen ürün yelpazesi ile destinasyonlarda önemli bir güç oluşturmaktadır (Şahin ve Ünver, 2015). Türk mutfağında, gastronomi turizmi içinde kullanılabilecek çok sayıda yiyecek bulunmaktadır.

Türk mutfağı, Türk kültürünün önemli bir unsuru ve evrensel kültür ortamının da sayılı mutfaklarından biridir. Türk mutfak kültürü zenginliğini, tarihi olaylara, coğrafi koşullara, kültürel, ekolojik ve ekonomik yapısına, gelenek ve göreneklerine ve tarih boyunca diğer evrensel kültürlerle etkileşim içerisinde olmasına borçludur (Sürücüoğlu ve Özçelik, 2008). Bu nedenle, ülkemizin her köşesinde farklı yöresel yiyecekler, yörenin kültürü ile yoğrularak zaman içerisinde oluşmuştur. Oluşan bu yöresel yiyeceklerin gastronomi turizmi açısından değerlendirilerek sunulması, yörelerin ekonomik ve sosyal gelişimi açısından oldukça önemlidir. Ödemiş İzmir iline bağlı bir ilçedir ve ekonomisi tarıma dayalıdır. Bu çalışma, Ödemişteki yöresel yemeklerin belirlenmesi ve gastronomi turizmi içinde sunulması amacıyla gerçekleştirilmektedir.

Çalışmanın literatür kısmında; gastronomi ve gastronomi turizmi kavramları açıklanarak, kırsal turizm ve gastronomi turizmi ilişkisi ortaya konmaktadır. Araştırma kısmında ise, Ödemiş'in yöresel yemekleri tespit edilerek reçeteleri belirlenmekte ve yöresel yiyeceklerin turistik çekim unsuru olarak sunulması için öneriler getirilmektedir.

\section{KAVRAMSAL ÇERÇEVE}

\section{Gastronomi ve Gastronomi Turizmi}

Gastronomi, Yunanca gastri (mide) ile nomos (yasa, kurallar) kelimelerinden gelmektedir (Tez, 2012) Yunan şair ve filozof Archestratus gastronominin babası (M.Ö. 4. yy.) olarak anılmaktadır. M.Ö. 350 yılında tamamlanan ve dünyanın ilk yemek kitabı olarak kabul edilen 
"life of luxury" en önemli eseridir (Moira, Mylonopoulos ve Kontoudaki, 2015). Gastronomi terimi, Joseph Bercholux'un 1801 tarihli Gastronomie ou L'Homme des Champs a Table (Gastronomi ya da Tarladan Sofraya İnsan) adlı eseriyle birlikte literatürde kullanılmaya başlanmıştır (Göker, 2011). İlerleyen dönemde, gastronominin klasik uygarlıkların mutfak kültürü ve kökleri ile ilgilenen bir bilim dalı olduğu kabul edilmektedir (Kivela ve Crotts 2006). Charles Monselet gastronomiyi "bütün şart ve yaşlarda tadılabilen haz" olarak tanımlamış ve bu kavram 1835 yılında Fransız Akademisi tarafından sözlüğe alınarak resmen onaylanmıştır (Mil 2009). Gastronomi ile ilgili pek çok çalışma yapılmaktadır. Bunlardan biri de "Larousse Gastronomique (Dünyanın En Büyük Mutfak Ansiklopedisi)"dir. Joel Robuchon tarafından 2005 yılında basılmıştır (Uyar ve Zengin, 2015:359).

Günümüzde gastronomi ile ilgili farklı tanımlara rastlamaktayız. Cömert ve Özkaya (2014, 63) gastronomiyi, ülke ya da bölge mutfaklarını birbirinden ayıran özellikleri, bir ülkenin ya da bölgenin yiyeceklerini, yeme-içme alışkanlıkları ve yiyecek hazırlama teknikleri olarak tanımlamaktadır. Akgöl (2012)'e göre gastronomi; yiyecek ve içecek ile ilgili kullanılan malzemelerin nasıl kullanılması gerektiğini anlatan, farklı mutfak kültürlerinin arasındaki benzerlik ve farklılığı ortaya koyan, bir yemekten alınan tadı doruk noktasına çıkarmaya ve tarih, kültür ve yemeği bir arada sunmaya çalışan bir bilim dalıdır. Hall ve Mitchell (2000) gastronomi turizmini; yemek gösterileri, festivalleri, restoranlar ve yemek tatma ve deneyimlemek için belirli yerlerin ziyaret edilmesi olarak tanımlamaktadır. Kivela ve Crotts (2006: 355) ise, gastronomiyi yemek, şarap ve mutfak sunumu olarak ifade etmektedir.

Gastronominin amac1; mümkün olan en iyi beslenme ile insanın korunması ve hayattan zevk almasının sağlanmasıdır. Bu bağlamda gastronominin çalışma konuları; yenilebilir tüm maddelerin, hijyenik bir ortamda hazırlanması, damak ve göz zevkini amaçlayarak sofraya, yenmeye hazır hale getirilmesidir (Şengül ve Türkay, 2016: 89). Tüm tanımların ortak özellikleri dikkate alındığında; gastronomiyi "temelinde belirli kültürlerin yansıması olan, yemek hazırlama, pişirme, sunum ve yeme-içme deneyimiyle ilgili bir sanat ve bilim dalı" şeklinde tanımlamak mümkündür. Bilim dalı olması nedeniyle gastronomi, belirli kuralları içermektedir. Tanıma ilave edilen "sanat" kavramı da haz ve estetikliğe çağrışım yapmaktadır (Sarışık ve Özbay, 2015:266). Tanımları incelediğimizde gastronominin "yemek üretmek" ten daha geniş boyutlu bir kavram olduğu anlaşılmaktadır. Gastronomiyi üretim ve tüketim boyutu altında iki bölümde incelemek, ne olduğu sorusuna açılık getirmeye yardımcı olacaktır.

Üretim boyutu ile gastronomi (Aksoy ve Sezgi, 2015:80-81):

- İyi yemek hazırlama, pişirme, sunma ve masa hazırlama bilimi ve sanatı,

- İyi yemek yeme ile ilgili faaliyetler ve iyi yemek yeme ile ilgili bilgi birikimi,

- Yemek pişirme ve hazırlama - aşçılık ile ilgili prensip ve uygulamalarıdır.

Tüketim boyutu ile gastronomi:

- İyi yiyecekten ve içecekten hoşlanma,

- İyi yemek yeme konusunda aşırı tutkulu davranma,

- Lüks ve lezzetli yiyeceklere düşkünlük ve tutkudur.

Üretim ve tüketim boyutu ile gastronomi:

- Yiyeceklerin uygun şekilde hazırlanması, pişirilmesi ve servis edilme süreci 
- Yemeğin uygun araç-gereçler kullanarak sunulup yenilmesi sanatı,

- Menüde bulunan yemeklerin ne kadar talep edildiği,

- Belirli bölgelerin mutfak kültürünü içeren; iyi yemek yeme bilimi ve sanatı,

- Damak tadının ve yemek yeme zevkinin, tarihsel bilgi, kültür, alışkanlık, yetenek ve emekle beğeniye uygun şekilde bir araya getirilmesidir. Gastronominin her iki boyutu ele alındığında (güzel bir yemek hazırlanması, sunumu ve hazırlanan üründen tüketicinin haz duyması aşamasına kadar olan süreç) kültür, tarih, yetenek, tecrübe vs. unsurlarla harmanlanmış, bir gastronomun emeğinin sergilenmesi söz konusudur (Aksoy ve Sezgi, 2015:82).

Son yıllarda yiyecekler, pek çok turistin seyahat nedenleri arasında, destinasyonların sahip olduğu mutfak kültürünü keşif seyahatlerin ana amaçları arasında yer almaktadır. Pek çok destinasyon da sahip oldukları mutfağı, turist çekim gücü olarak kullanmakta ve bu alanla ilgili niş pazar olarak faaliyet göstermektedirler. Turistik destinasyonlardaki yiyecek ve pişirme yöntemleri kısacası mutfak kültürü, bölgenin kültürel karakteristiklerini ve özelliklerini barındıran görünmeyen miras olarak, destinasyonları uluslararası noktada geliştirebilmektedir. $\mathrm{Bu}$ sebeple mutfak turizmi, bölgesel açıdan turizm pazarını temsil etmekte ve bölgelere rekabetçi üstünlük sağlamaktadır (Horng ve Tsai, 2012). Yiyeceklerin turizm amaciyla kullanımını tanımlamak için "gastronomi turizmi", "mutfak turizmi", "beslenme turizmi", "gurme turizmi", "gastronomik turizm" ve "yiyecek turizmi" gibi kavramlar kullanılmaktadır (Alyakut ve Üzümcü, 2017:1841). Ülkemizde "gastronomi turizmi" yaygın olarak kabul görmektedir.

Türk gelenek-görenek, örf ve adetlerinde yiyecek-içecek unsurunun önemli bir öğe olduğu anlaşılmakta, bu öğenin toplumun sosyal kaynaşmanın bir unsuru olduğu daha net biçimde görülmektedir (Avcıkurt vd., 2007). Gastronomi yiyecek ve içecek kültürünün bilime ve sanata dönüşmesi olarak tanımlanırken, gastronomi turizmi gastronomik destinasyonlara yapılmış eğlenme amaçlı yiyecek ve içecekle ilgili rekreasyonel deneyimsel aktivitelerin bütünü olarak tanımlanmıştır. Bu aktiviteler gastronomik festivaller, pazarlar ve yiyecek üretim yerlerine seyahatler, gıda fuarları, yemek şovları, yöresel ve kaliteli yiyecekleri deneyimleme aktiviteleridir. Bununla birlikte özel bir yemeği tatmak, yemeklerin farklı üretim süreçlerini görmek veya ünlü bir şefin elinden yemek yine bu kapsamda ele alınmaktadır (Şahin ve Ünver, 2015;64-65). Long, gastronomi turizmini, “bilinenden farklı bir mutfak kültüründeki yiyeceklerin tüketilmesini, hazırlanmasını, sunulmasını ve mutfağını, öğün sistemlerini, yeme biçimlerini keşfetmek amacıyla gerçekleştirilen turizm şekli" olarak tanımlamıştır (akt: Aksoy ve Sezgi,2015:81). Başka bir tanıma göre "Gastronomi turizmi, ana motivasyon kaynağı özel bir yemeğin tadımı veya bir yemeğin üretim aşamalarını görmek amacıyla, yöresel veya kırsal alanları, yiyecek üreticilerini, restoranları, yemek festivallerini ve özel alanları ziyaret etmektir" (Yüncü, 2010: 29).

Klasik turizm anlayışının tüm dünya üzerine yayılması sonucunda zamansal ve mekânsal yığılma orya çıkmıştır. Tüm ülkeler bu soruna çözüm olması ve ekonomilerine daha fazla katkı sağlayabilmek için turizmi yıl içine yayabilecek turizm çeşitlerine yönelmektedir. Kırsal turizm ve gastronomi turizmi de bu turizm çeşitlerindendir. Her iki turizm çeşidinin sunum açısından birbiri ile uyumluluğu, kırsal turizm ile gastronominin birlikte sunumuna olanak tanımaktadır. Hatta gastronomi turizmi kırsal turizmin önemli ögelerinden bir tanesidir demek mümkündür. 


\section{Kırsal Turizm ve Gastronomi İlişkisi}

Günümüzde turizm anlayışında meydana gelen değişiklikler ve kırsal alanların değişimi kırsal turizm çeşidinin gelişmesine zemin hazırlamaktadır. Kırsal turizm; bir çekicilik unsuru olarak dünyanın pek çok ülkesinde insanların tatil anlayışlarını değiştirmektedir. Özellikle boş zaman aktivitelerini gerçekleştirmek isteyen turistlerin dikkatini kırsal alanlara çekebilen bu turizm çeşidi, kırsal kültürün bir parçası olan; yemek, doğal çevre, temiz yaşam kaynakları ve tarımla bütünleşmekte aynı zamanda diğer turizm türleriyle de kolay entegre olabilmektedir (Deveci vd., 2013:30).

Turizme katılan kişilerin istek ve ihtiyaçları istikametinde şekil alan bu alternatif turizm çeşitlerinden biri de kırsal turizmdir (Çeken vd., 2007: 6). En genel haliyle kırsal alan; kent olarak tanımlanan yerleşme alanının dışında kalan tarımla ilgili etkinliklerin yapıldığı alanları da içeren köy, mezra vb. adlarla anılan insan yerleşimlerinin var olduğu alanlar olarak tanımlanabilir (Şerefoğlu,2009). Soykan (1999); kişilerin doğal ortamlarda dinlenmek ve değişik kültürlerle bir arada olmak amacıyla bir kırsal yerleşmeye gidip, orada konaklamaları ve o yöreye özgü etkinlikleri izlemeleri ya da katılmalarıyla gerçekleşen bir turizm türü olarak tanımaktadır. Kırsal turizmde hizmet sunanlar, ziyaretçilerin ziyaret edilen yerdeki atmosferi test etmesi ve kırsal ürünleri denemelerine imkan sağlarlar (Veer and Tuunter, 2005). Böylece günlük kırsal yaşam içine kabul edilen turistler hem kırsal kültürü öğrenirler hem de aktif tatil geçirirler (Çakır vd., 2010:2).

Kırsal turizmin düzenlendiği yöre için önemi ana başlıklarla aşağıdaki gibi sıralanabilir (Soykan, 2003).

- Kirsal turizm, her mevsim yapılabilen bir turizm türüdür.

- Kırsal turizm, turizmin coğrafi dağılışında denge unsurudur.

- Kırsal turizm birçok turizm türüne entegre olabilir.

- Kırsal turizmde rekreasyonel etkinlikler çok çeşitli ve özgündür.

- Kırsal turizmin turist profili farklıdır.

- Kırsal turizm, doğal çevrenin ve kültürel mirasın korunmasına katkıda bulunur.

- Kırsal turizm, sürdürülebilir turizm anlayışına hizmet eder.

- Kırsal turizm bir ülkenin tanıtımında önemli bir araçtır.

Soykan'ın (2003)'te de belirttiği gibi kırsal turizm, turizmin mevsimlik yığılmasını önleyen, pek çok turizm türü ile birlikte sunulabilen, özellikle sunulduğu bölgenin doğal ve kültürel anlamda korunmasını destekleyen bir turizm çeşididir. Gastronomi turizmi de kırsal turizm ile birlikte harmanlanmaktadır.

Gastronomi turizminin kökeni tarım, kültür ve turizmde yatmaktadır. Bu üç unsur; gastronomi turizminin bölgesel bir çekicilik ve deneyim olarak pazarlanmasına ve konumlandırılmasına fırsat sağlamaktadır. Tarım; ürünü sunmakta, kültür; tarihi ve otantikliği, turizm ise; alt yapıyı ve hizmetleri sağlamaktadır. Tüm bu unsurlar, gastronomi turizmi altında buluşmaktadır (Özkaya ve Can, 2012:875). Yerel mutfaklar, bölge kültürünün içine girebilmenin ve bölge kültürü hakkında bilgi sahibi olabilmenin en önemli araçlarındandır. Bir destinasyonu ziyaret eden turistler, söz konusu destinasyonun yerel mutfağını yakından tanımak ve yemeklerin tadına bakmak istemektedirler (Alyakut, 2017: 107). Bunun sonucunda insanlar değişik tatların olduğu yerlere doğru seyahat etmektedirler. Bu lezzetleri tatma isteği günümüzde artış göstermektedir ve söz konusu olan yemeklerin üretimden tüketimine kadar incelenmesi ve bu 
süreçte kullanılan malzemelerin sadece o yöreye ya da bölgeye ait olması ve böylece bölgenin çekiciliğinin artırılması gerekmektedir (Canbolat ve Çakıroğlu, 2015). Hu ve Ritchie de bir destinasyonun ziyaret edilmesinde havası, konaklaması ve manzarası ile birlikte yemeğinin de en önemli tercih nedenlerinden biri olduğunu vurgulamaktadır (1993:25-34). Yemek insan hayatının vaz geçilmez ihtiyaçlarından bir tanesi olması yanında, önemli bir haz alma aracıdır. Günümüzün yoğun şehir hayatından uzaklaşmak isteyen insanlar, kırsal yörelere giderek burada bulunan yöresel yiyecekleri tadarak, yapımını öğrenerek, festivallere katılarak bu ihtiyaçlarını gidermektedir.

Kırsal turizm, kırsal yörelerde önemli bir kalkınma aracıdır. Gastronomi turizmi ise kırsal turizm ile içi içe geçmiş bir turizm çeşididir. Smith ve Hall (2003)'da gastronomi turizmi ve bölgesel kalkınma arasındaki ilişkide en önemli unsurlardan birinin yöresel yemeklerin sunumu olduğunu ifade etmektedir. Aslan (2010:44), yöresel lezzetlerin özellikle korunması gereken unsurlar olduğunu; milletlerin birçok adetleri gibi yiyeceklerinde de kültür, tarihi oluş ve tabiat varlığının etkileriyle özellikleri bulunduğunu ifade etmektedir. Yöresel yiyeceklerin özelliklerinin korunarak, kırsal turizm içerisinde sunulması, o yörenin turizm potansiyelini arttırarak ekonomik ve sosyal açıdan gelişmesine imkan sağlarken, bu lezzetlerin sonraki nesillere aktarılmasını da sağlayacaktır. Bu amaçla kırsal yörelerdeki gastronomik ürünlerin turizmde sunulması için turlar düzenlenmesi yaygın bir uygulamadır.

Yüncü (2010: 31), gastronomi turizmine yönelik düzenlenen turları genel olarak üç kategoride toplamıştı;;

- Yemeklerin nasıl pişirilmesi gerektiğine dair eğitimleri içeren turlar; bu turlar için örnek bölgeler, Fransa, İtalya ve İspanya gösterilebilir. Bu bölgelere düzenlenen turlar genelde yemek hazırlığı üzerine düzenlenen ve şarap tadımı turlarıdır.

- Bu alanda önem arz eden bir bölgenin yerel yemeğini yemek veya dünyaca ünlü bir şefin yaptığı yemeği tatmak, hazırlığını izlemek için düzenlenen turlar; bu turlar için, İtalya'da zeytinyağı, Fransa'da peynir ve İspanya'da tapas denilen mezelerin tadımının yapıldığı turlar örnek verilebilir.

- Özellikle sadece o bölgeye özgü bir ürünün tadılmasına ve o ürünün üreticileri ile buluşma imkanı sağlayan turlar; bu turlar için Kosta Rika'ya yapılan kahve turları, Japonya ve Sri Lanka'ya yapılan çay turları ve Belçika ve İsviçre'ye yapılan çikolata turları örnek verilebilir.

Uluslararası Mutfak Turizm Derneği'nin web sitesinde, gastronomi turizminin özellikleri şu şekilde değerlendirilmektedir (Kivela ve Crotts, 2006: 360: akt: Kodaş ve Dikici):

- Neredeyse turistlerin tamamı seyahat esnasında dışarıda yemek yemektedirler ve akşam yemekleri yerel yiyecek ve insanları tanımak için bir fırsattır

- Gastronomi turizmi; daima üç gözde turizm faaliyetlerinden biridir.

- Diğer seyahat faaliyetlerinin aksine, gastronomi; günün her saatinde ve her türlü hava koşulunda yıl boyunca kullanılabilir.

- Yemek pişirme ya da gastronomi sanatı ve şarap tadımı, beş insan duyusunu da-görme, ses, koku, tat ve dokunma- etkileyen bir sanattır.

- Şarap ve yöresel mutfak ile ilgilenen turistler ve müze, alışveriş, müzik, film, festival gibi kültürel konular ile ilgilenen turistler arasında yüksek ve pozitif bir korelasyon vardır.

- Seyahat esnasında mutfağa olan ilgide, belirli bir yaş, cinsiyet veya etnik gruba aitlik yoktur.

- Çoğu zaman, gastronomi turistleri kaşifler'dir. 
-Gastronomi, her yeni turistin etkileşim yoluyla, yaşayarak deneyimleme talebini karşılayabildiğinden deneyimseldir.

\section{ARAŞTIRMA METODOLOJİsi}

\section{Araştırmanın Amacı ve Yöntemi}

Araştırmada, İzmir ili Ödemiş ilçesinin geleneksel yemeklerinin ortaya çıkarılması ve gastronomi turizmi potansiyelinin belirlenmesi amaçlanmaktadır. Bu amaçla, öncelikle arşiv taraması yapılmış, daha sonra elde edilen bulgular yerli halk ile görüşülerek doğrulanmıştır.

Arşiv taraması, geçmişe dönük tutulan her türlü yazılı ve sözlü kayıtlar, arşiv ve doküman taramasını oluşturmaktadır. Bunlar; yazılı kaynaklar, gazete, dergi, kitap, ansiklopedi, rapor, mektup vb. yayınlarıdır. Arşiv ve dokümanların elektronik ortamda yer aldığı göz önüne alınarak, bu tür arşivlerin daha çok okuyucuya ya da araştırmacıya ulaştırılabilmesi için kolaylık yaratması açısından anahtar kelime iyi belirlenmelidir. Konuyla bütünleşen, konunun ana hatlarını çok iyi özetleyen anahtar kelimeler seçilmelidir (Kozak, 2018:88). Araştırmada ilk olarak internet üzerinden arşiv tarama yöntemine başvurulmuştur. Arşiv taramada kullanılacak anahtar kelimeler için gastronomi konusunda uzmanlaşmış, en az doktora derecesine sahip dört akademisyenden görüş alınmış ve anahtar kelimeler belirlenmiştir. Sonraki aşamada anahtar kelimeler arama motorunda aratılarak, doküman taraması yapılmış ve yemek isimleri belirlenmiştir. Belirlenen yemek isimleri yöre halkına sorularak doğrulanmıştır.

“Ödemiş Yemekleri”, "Ödemiş yöresel yemekleri”, "Ödemiş Mutfağı” anahtar kelimeleri arama motorunda taranarak bulunan ilk 20 sonuç değerlendirilmiş ve en çok adı geçen 12 yemek seçilmiştir. Bu sonuçları doğrulamak için; yöre halkından 60 yaş ve üzerindeki 6 kişiyle görüşülmüş ve sonuçlar teyit edilmiştir.

\section{Araştırma Bulguları}

Yapılan araştırma sonucunda Ödemiş'in yöresel yemekleri; Ödemiş köfte, töngül pide, ekmek dolması, keşkek, saç pidesi, kabak sinkonta, otlu sini pidesi, nohut mayalı ekmek, patates galgıtması (hoplatması), heybeli çorba, peksimet, avutmasıdır.

\section{Ödemiş İlçesi Genel Bilgi}

Ödemiş, İzmir'in güney doğusunda yer almaktadır. Yüzölçümü, 1082.6 km², rakımı 123 m ve toplam nüfusu 132.511 kişidir. İzmir kent merkezine $112 \mathrm{~km}$ uzaklıkta yer alan ilçeye, karayolu ve demiryolu ile ulaşım sağlanmaktadır. Ödemiş-Torbalı-İzmir hattında günde 5 kez karşılıklı sefer vardır. Ayrıca sabah 05:00'dan akşam 21:00'a kadar yarım saat arayla otobüs seferleri mevcuttur (www.odemis.bel.tr).

\section{İlçe Ekonomisi}

İlçede ekonomisinin önemli bir bölümü tarıma dayalı olup, 101.814 hektarlık alanın \%47'si tarım arazisidir. İlçede 48.000 hektar tarım alanı, 33.500 hektar orman alanı, 8.100 çayır-mera, 13.800'hektar da tarım dışı alan bulunmaktadır. İlçede yaklaşık olarak 32.000 aile tarımla geçimini sağlamaktadır. Bunun dışında ilçede hayvancılıkla da yaygın bir şekilde uğraşılmaktadır. İlçede; patates, arpa, mısır, bakla, taze fasulye, barbunya, börülce, taze soğan, 
sarımsak, karpuz, salatalık, domates, kiraz, incir ve kestane üretilmektedir. Özellikle; patates, domates, kiraz, incir ve kestane üretimi ilçe ekonomisine önemli katkı sağlayan ürünlerdir (Ödemiş Ticaret Odası, 2018).

\section{Turizm Olanakları Genel Değerlendirme}

Ödemiş ilçesi tarihine ilişkin en eski bilgi, M.Ö. 11 bin yıl öncesine ait Konaklı Beldesi'nin 700m Güneydoğusundaki Soğukluk Deresi kanyonunda bulunan kaya altı sığınandaki şematik kazıma figürlere dayanmaktadır. İlçenin bugünkü temelleri ise 1684 yılında Ötemiş Türkmen oymağının yerleşik duruma getirilmesi ile atılmıştır. Ödemiş adı 1451 yılında Otamış olmuş, 1684 yılında Ötemiş olarak değişmiş, 1820 yılında da son değişiklikle bugünkü halini almıştır (https://izmir.ktb.gov.tr). Kurtuluş savaşında, Kuvayi milliye grubunun ilk direnişinin Ödemişte gerçekleşmiş olması önemlidir. Şimdi İlk Kurşun ismini alan Hacı İlyas Köyü yakınlarındaki çatışma "illk Kurşun Savaşı" olarak Milli Mücadele tarihinde yer almaktadır (Berber ve Bulut, 2013).

İlçe; höyükler, tümülüsler, tarihi sitler, kaya mezarları, kaleler, tarihi anıtlar, camiler, türbeler, müzeler olmak üzere çok sayıda kültürel veriyi barındırmaktadır. Bunun yanında; inanç turizmi, yayla turizmi, yamaç paraşütü, Bozdağ' da kış turizmi, kuş gözetleme turizmi, botanik turizmi imkanları mevcut olup, kamp ve karavan turizmi için uygun alanlar bulunmaktadır. İlçede Bozdağ'ın kış turizmi merkezi olması, Birgi'nin tarihi ve bozulmamış yapısı oldukça önemlidir. İlçede yılın farklı zamanlarında; sergiler, yarışmalar ve festivaller de düzenlenerek turistik hareketlilik yaratılmaktadır. Cumartesi günleri kurulan yerli üreticilerin sebze ve meyvelerini sunduğu pazar ve bu pazardaki, yöre kadınlarının el işlerini sunduğu kadınlar pazarı turizm açısından yoğun talep görmektedir. Yöreye bu pazarları ziyaret etmek için günlük turlar yapılmaktadır (Akpulat, 2015).

\section{BULGULAR}

\section{Ödemiş İlçesi Yöresel Yiyecekleri}

\section{Ödemiş Köfte}

İlçede sadece Ödemiş köfte üreten kayıtlı 37 işletme bulunmaktadır (www.odemisto.org.tr)

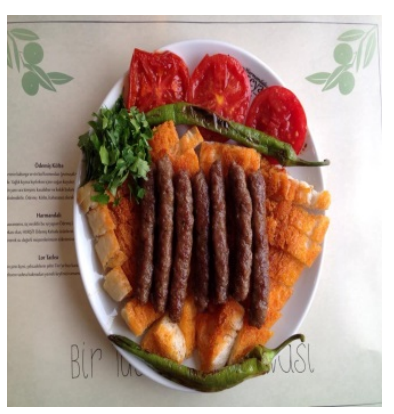

Resim 1: Ödemiş Köfte

Kaynak: https://www.facebook.com/harmandaliodemis

Malzemeler: Dana eti, (kaburga ve önkol kısmı) kıyma yağlı olmalı. Soğan, 1 kg ye 250 gr irmik konur, kimyon, karabiber, kekik, tuz. 
Sosu İçin: 1 yemek kaşığı tereyağı, 1 tatlı kaşığı kırmızı toz biber.

Servis İçin: Soğan piyaz, domates, biber, maydanoz.

Yapılışı: Kıyma kıyılırken içine soğan eklenerek iyice karışmaları sağlanır. Kıyma miktarına göre irmik eklenir. (1 kg kıymaya, 250 gr irmik eklenir.) Kimyon karabiber, kekik ve tuz eklenerek iyice yoğurulur. Özel makinada şekil verildikten sonra, bir gece bekletilir (https://www.youtube.com/watch?v=e9B1isQlPAk).

Odun ateşinde kızartılması tercih edilir. Isıtılmış ızgaraya zeytinyağı dökülür. 3-5 dakika kızardıktan sonra, alınarak yandaki ızgarada bulunan; tereyağı, kırmızı toz biber karışımda tekrar kızartılır. Ekmek bu sosa hafif bulanarak tabağa alınır ve üzerine köfteleri yerleştirilir. Yanına söğüş soğan, kızarmış birer ve domates ile servis yapılır. (http://www.nurmutfagi.de/odemis-koftesi-nasil-yapilir-tarifi-odemis-yagli-ekmek-arasi-koftetarifi/).

\section{Töngül Pide}

İlk yapan kişinin soyadı ile anılan Töngül Pide, Ödemiş tulumu, maydanoz, az miktarda kıyma ile odun fırınında pişirilir. Fırından çıktığında üzerine zeytinyağı sürülür ve bir kere daha Ödemiş tulumu rendelenir. Açık ve kapalı çeşitleri yapılmaktadır. Töngül pide 125 yıllık tescilli bir markadır. İşletme halen ilk açıldığı yerdedir ve tarihi özellik taşıması nedeniyle tadilat ya da genişletme yapılamamıştır. İşletmede başka pide çeşidi üretilmemektedir (Kişisel Görüşme: İsmail Töngül, akt: Akpulat, 2015).

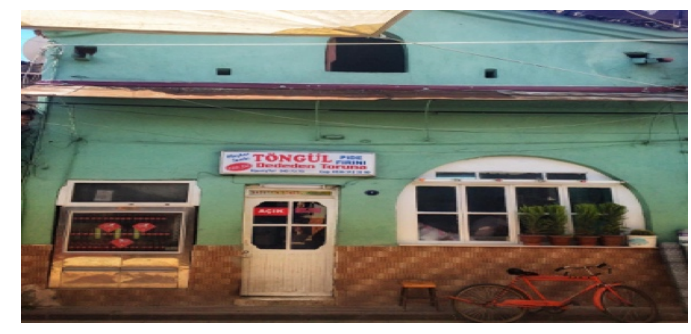

\section{Ekmek Dolmasi}

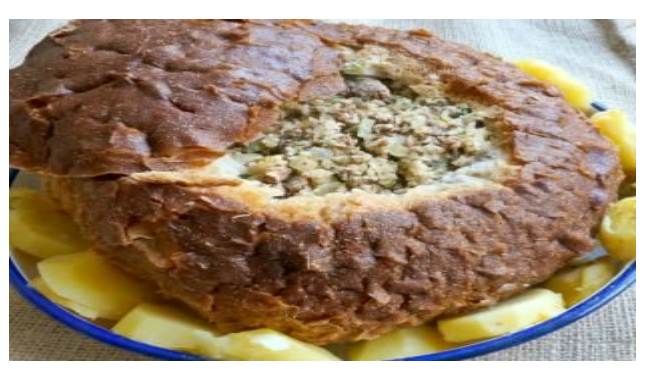

http://odemisliyiz.com/odemis-mutfagi/odemis-ekmek-dolmasi/

Malzemeler: Bir adet yuvarlak (dolmalık) ekmek, 250-300 gr kıyma, 1 adet soğan, 3 yemek kaşı̆̆ tereyağı, 1 demet maydanoz, 2 yemek kaşığı salça, tuz, karabiber, pul biber 
Yapılışı: Ekmek taze ise buzdolabında 2 gün bekletilmesi gerekir. Yemeğin özelliği bayat ekmekle yapılmasıdır. Ekmek dolması için üretilen bu ekmeklerin üst kısmında kapak olur ve çok kolay bir şekilde çıkarılır. Kapak çıarılarak ekmeğin iç kısmı tamamen boşaltılır. Bir tencerede 2 yemek kaşığı tereyağı eritilir, kıyma ilave edilerek kavurulur. Daha sonra ince kıyılmış soğanlar ve salça ilave edilerek kavrulmaya devam edilir. Tuz, pul ve karabiber ile ince kıyılmış maydanozu da ekleyip karıştırdıktan sonra ocağın altı kapatılır. Çıkarmış olduğumuz ekmek içinin önceden iyice ufalanıp hazırlanmış olması gereklidir. Hazırlanan bu harca, ekmek ufaklarını ilave ettikten sonra karıştırılır ve karışım ekmeğin içine doldurulur. Ekmeğin kesilen kapağı üzerine kapatılır. 1 yemek kaşığı tereyağını eritip içine 3 yemek kaşığı salça ilave ederek kavurulur ve bu karışım ekmeğin dışına sürülür. Hazırlanan ekmeğin buharda pişmesi gereklidir. Büyükçe bir tencerenin içine 7-8 bardak su doldurduktan sonra, tencerenin içine bir süzgeç yerleştirip (ekmeğin su ile temasını kesecek şekilde) hazırlanan ekmek üzerine bırakılır. Ekmeğin, su kaynadıktan sonra, kısık ateşte 30 ila 45 dakika arasında pişirilmesi gereklidir. Aynı yöntemle, fırında da $170 \mathrm{C}$ de 20 dakika pişirebilmesi mümkündür (http://odemisliyiz.com/odemis-mutfagi/odemis-ekmek-dolmasi/).

\section{Keşkek}

Malzemeler: 2 su bardağı buğday, 2 soğan yarım kg. kuzu gerdan, sıvı yağ, tuz, karabiber.

Sosu İçin: 1 çorba kaşığı tereyağı, 1 çorba kaşığı salça, tuz, karabiber, kekik.

Yapılışı: Buğday önceden haşlanır. Soğan tencereye doğranarak kavurulur. Üzerine haşlanmış olan buğday eklenir. Haşlanmış olan kuzu eti, lif lif ayrılır ve tencereye ilave edilir. Bir tahta kaşıkla devamlı dövülerek pişirilir. Bu işlem malzemelerin iyice özleşmesini sağlar. Kıvamı ayarlamak için tencereye et suyu ilave edilir. Kıvamı oluşana kadar pişirilmeye devam edilir. Sosu için 1 çorba kaşığı tereyağı tavada eritilir. Üzerine salça, tuz, karabiber ve kekik ilave eklenerek 2-3 dakika kavrulur. Keşkek tabağa alınır ve üzerine sosu ilave edilir (http://odemisliyiz.com/odemis-mutfagi/keskek/).

\section{Peksimet (Pesmet)}

Akşamdan parçalanmış nohut, buğday unu, 1lık su ile hamur yoğrularak tatlı maya elde edilir. Ertesi sabah büyük bir leğende tatlı maya, su, buğday unu, mısır unuyla hamur yoğrulur. (Bazı köylerde arpa veya çavdar unu da eklenir), 2-3 saat mayalanmaya bırakılır. Zeytinyağı ile yağlanan tavalara hamur yayılır. Her mahallede bulunan geleneksel taş firınlar odunla, çalılarla yakılarak iyice 1sıtılır. Odunlar iyice yanıp kor haline gelince ekmek tavaları kürekle fırına yerleştirilir. Pişen peksimet tavaları fırından çıkarılıp soğutulur. Tavadan bütün olarak çıkarılan peksimetler dilimlenir. Fırın tekrar iyice isıtılır. Peksimetler fırına yerleştirilir. 2-3 gün fırında kalır (Yilmaz, 2017).

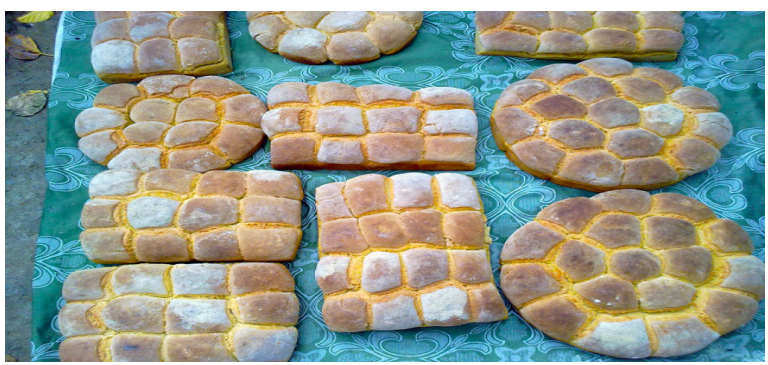

www.odemisliyiz.com

\section{Saç Pidesi}


Malzemeler (4 kişilik): 2 bağ 1sırgan otu, 1 bağ 1spanak, 1 bağ pazı, 1 bağ maydanoz, yarım bağ taze soğan, 1 tatlı kaşığı kuru nane, yarım kilo un, 100 gram çökelek peynir, 1 çay bardağ 1 zeytinyağı, 1 çay kaşı̆̆ı tuz.

Yapılışı: Pidenin içini oluşturacak malzemeler (ısırgan otu, ıspanak, pazı, maydanoz, taze soğan) bir gün önce akşamdan yıkanır, ince ince doğranır ve serilerek sabaha dek kurumaya bırakılır. Sabah büyükçe bir kap içerisine alınıp çökelek ilave edilir ve harmanlanır.

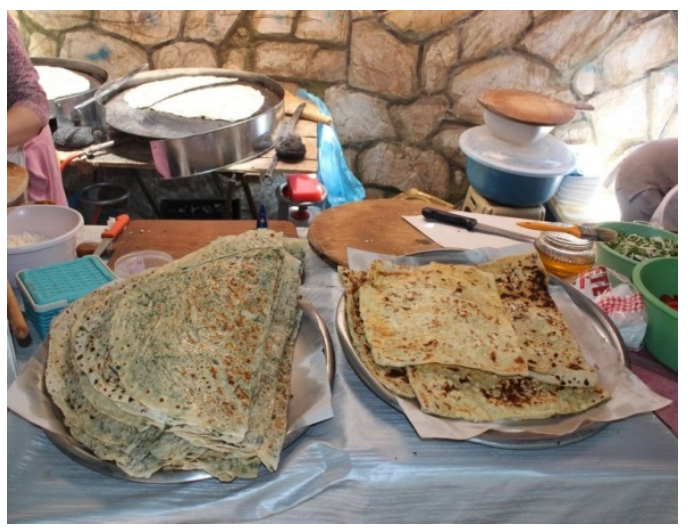

Kaynak: https://www.yeniasir.com.tr

Un, bir kap içerisine alınır. 1 yemek kaşığı zeytinyağı, 1 çay kaşığı tuz ve uygun miktarda su ilave edilerek, kulak memesi yumuşaklığına gelinceye kadar yoğrulur ve yarım saat dinlenmeye bırakılır. Hazır hale gelen hamur yumurta büyüklüğünde parçalara ayrılır ve yuvarlanarak tepsi içerisine dizilir. Hazırlanan ve tepsiye dizilen hamurlar senit (üzerinde yufka açılan ekmek tahtası) üzerinde oklava yardımıyla yuvarlak ve ince bir şekilde açılır. Daha önce harmanlanan iç malzemesinden iki yemek kaşı̆̆ı alınarak, ince bir şekilde açılmış olan hamurun üzerine (yarısını dolduracak şekilde) serpilir, malzeme olmayan tarafı ile kapatılır. Kapatılan içli hamur kızgın saç üzerine konulur. Arada bir dikkatlice çevrilerek her iki tarafının pişmesi sağlanan saç pidesinin piştiği, hamurun hafifçe kızarmaya başlamasıyla anlaşılır. Pişmiş olan saç pidesi, küçük bir fırça yardımıyla (zeytinyağı ile) yağlanır ve dürüm şeklinde ya da doğranarak tabakta servis edilir (http://odemisliyiz.com/odemis-mutfagi/odemis-sacpidesi/).

\section{Kabak Sinkonta}

Malzemeler: 1 kg taze kabak, 2 baş soğan, 1 çay bardağı zetinyağı, 2 yemek kaşığı sirke, 1 yemek kaşığı salça, 1 yemek kaşığı un, yarım limon, 6 diş sarımsak, 2 yemek kaşığı kuru nane, 1 tatlı kaşığı kırmızı pul biber, 1 çay kaşı̆̆ı tuz

Yapılışı: Kabağı soyup yıkadıktan sonra parmak kalınlığında büyükçe parçalar halinde doğranır ve tepsiye dizilir. Üzerine ince uzun kesilmiş soğan dilimleri sıralanır. 1 çay bardağ eritilmiş salça, un, sirke, limon suyu, zeytinyağı, ezilmiş sarımsak ve tuz iyice çırpılır. Karışım kabakların üstüne gezdirerek dökülür. En üste pul biber ve nane serpip fırına sürülür. 200 derece ısıda önce tepsinin üstü kapalı, sonra açık olarak 1 saat kadar pişirilir. (Servis sırasında istenirse üzerine sarımsaklı yoğurt dökülebilir) (https://lezzetler.com/kabak-sinkonta-izmirvt49476). 


\section{Otlu Sini Pidesi}

Malzemeler: 3 su bardağı un, 1 paket instant kuru hamur mayası, 1 tatlı kaşığ şeker, Aldığı kadar 1lık su, (1-1,5 su bardağı), 1/2 su bardağı sıvı yağ.

İç Harcı: 250 g sspanak, 1 çay bardağı peynir veya çökelek, 2-3 adet taze soğan yaprakları.

Üzeri İçin: Susam veya çörek otu.

Yapılışı: Un, maya, tuz, şeker ve aldığı kadar ılık su ile ele yapışmayan yumuşak bir hamur yoğurulur. Hamurun üzeri kapatılıp 10-15 dakika dinlendirilir. Bu arada iç harcı hazırlanır. Tepsiye yarım su bardağı sıvı yağı döktükten sonra, üzerine yoğurulan hamur yerleştirilir. Hamur el ile bastırarak düzleştirilir ve ortasına iç harcı koyulur. Hamurun kenarları ortada birleştirilir. Tepsideki yağla eli yağlayıp, hamur bastırılarak tepsiye göre yayılır. Üzerine yumurta sarısı sürdükten sonra, susam ya da çörek otu serpilir. 170 derece fırında üzeri kızarana kadar pişirilir (http://odemisliyiz.com/odemis-mutfagi/odemis-birgi-sini-pidesi/).

\section{Nohut Mayalı Ekmek}

Malzemeler: 1, 5 su bardağı el yakan su, 1 çay bardağı nohut, 2 çay kaşığı tuz, 3 çay kasığı tuz, 2 kesme şeker, 3 yemek kaşı̆̆ı un, 1 kiloluk cam kavanoz, tahta kaşık.

Yapılışı: Öncelikle mayanın hazırlanması gerekir. Sıcak su ile yıkanmış kavanoza, 3 yemek kaşı̆̆1 un, 1 çay bardağı kırılmış nohut, 2 çay kaşı̆̆ı tuz konulduktan sonra üzerine, $1.5 \mathrm{su}$ bardağı sıcak su eklenerek tahta kaşıkla karıştırılır. Kavanozun tamamını havlu, sofra bezi gibi örtülerle örterek vücut sıcaklığına gelinceye kadar soğutmak gerekir. Bu sıcaklığa ulaştıktan sonra 6 saat beklenir. Daha sonra kavanoz açılarak, 1 çay bardağı sıcak su ve kesme şeker eritilip kavanoza eklenir. Tahta kaşıkla kavanozu karıştırıp, üzerini örtüp 12 saat daha beklenir. 12 saat sonunda köpürmüş maya hazır hale gelmiş olur. Hamur yapmak için, büyük bir kaba un koyulur ve üzerine mayalı kavanoz açılır. Süzgüden geçirerek nohutlar alınır. Sonra 3 çay kaşığı tuz, un ve sıcak su ile yoğurulur. İstenen miktarda un ve sıcak su eklenerek çoğaltılır ve yoğurulur. Ele yapışan, ama akmayan bir hamur kıvamı elde edilmelidir. Hamur yoğurulan kabın altına başka bir kaba, sıcak su koymak kabarması açısından yararlı olur. Hamurun üzerini örtüp 2 saat bekletilir. Kabarmış olan hamuru soğan sürüp yağladığımız tepsiye döktükten sonra ve tepside 15 dakika bekletilir. Baloncuklar oluşmaya başlayacaktır. Fırını 200 derece ısıttıktan sonra tepsi yerleştirilmelidir. Üzeri kızarınca fırın 150 dereceye düşürülür. Fırından çikarınca üzerine islak bez örtmek gereklidir (https://www.nefisyemektarifleri.com/nohut-mayali-odemis-ekmegi/).

\section{Peksimet Avutması}

Malzemeler: Ödemiş peksimeti, ısırgan otu, (yoksa marul), pırasanın beyaz kısmı, (yoksa taze soğan), domates, sızma zeytin yağ, çökelek, tuz, zeytin, biber.

Yapılışı: Peksimet ıslatıp el bezinin arasında bekletilir. Tüm yeşillikler, domates, biber yıkanıp küçük küçük doğranır. Yumuşayan peksimetler, karışımın üzerine ufalanır. Çökelek, zeytinyağı, tuz ve siyah zeytinler ilave edilip karıştırılır. 


\section{Heybeli Çorba}

Malzemeler: 1,5 su bardağı kuru börülce, 1 su bardağ iri bulgur, 1 adet büyük boy kuru soğan 3 yemek kaşığı zeytinyağı yarım yemek kaşığı biber salçası, yarım yemek kaşığı domates salçası, 5 su bardağı su, tuz.

Süslemek İçin: Kurutulmuş biber.

Yapılışı: Öncelikle kuru börülce akşamdan suyun içerisine konarak ıslatılır. Islanan börülcelerin suyu dökülür ve tekrar yıkanarak süzülür. Bir tencerenin içerisine kaynamış su doldurur ve kuru börülceler yumuşayana dek pişirilir. Diğer taraftan soğanın kabukları soyulur ve tavla zarı şeklinde yemeklik olarak ince ince doğranır. Tencerenin içerisine yağ ve soğanlar koyulur ve soğanlar pembeleşene kadar kavurulur. Kavrulan soğanların içerisine, biber salçası ve domates salçası ilave edilerek salça kokusu çıkana kadar kavurulur. Salçanın kokusu çıkınca üzerine iri bulgur koyulur ve karıştırarak 1 dakika kadar kavrulur. Sonra üzerlerine pişen kuru börülceleri ve sıcak 5 bardak su eklenir. Salçaların tuzu göz önünde bulundurularak, tadına bakıp gerektiği kadar tur ilave edilir. Ocağın altını kısılır ve tencerenin ağzı kapatılır. Arada karıştırarak 15-20 dakika koyulaşana kadar pişirilir. İstenen kıvama geldiğinde ocağın altı kapatılır. İsteğe göre, kurutulmuş biberler ufalanarak çorbanın üzerine serpilir (Hatice İçel görüşme).

\section{Patates Galgitması (Hoplatmasi)}

Malzemeler: İstediğiniz miktarda küçük patates (bebek patates), tuz, yarım fincan kadar zeytinyağ1.

Üzerine: İsteğe göre sarımsaklı yoğurt ve domates sos.

Hazırlanışı: Bebek patatesler güzelce yıkandıktan kabuklu olarak suda bekletilir. İyice süzülür ve üzerine tuz serpilir. Tavaya zeytinyağı dökülür ve patatesler içine atılır kapağı kapatılır ve altı kısılır. Ara ara tava hoplatarak karıştırılır. Kaşıkla karıştırılırsa patatesler ezilir. Kızaran patatesler tabağa alınır. Üzerine isteğe göre sarımsaklı yoğurt, domates sosu dökülebilir (Hatice İçel görüşme).

\section{TARTIŞMA, SONUÇ ve ÖNERILLER}

Ödemiş; tarihi 1600'lere uzanan, ekonomisi tarım ve hayvancılığa dayanan, verimli topraklara sahip İzmir iline bağlı bir ilçedir. İlçede yayla turizmi, kültür turizmi, inanç turizmi, kış turizmi, kuş gözetleme turizmi, botanik turizmi ve kamp turizmi yapılabilecek veriler mevcuttur. Bunun yanında ilçenin gastronomi turizmine uygun yöresel yemekleri de vardır (Akpulat, 2015).

Araştırma sonucunda Ödemiş ilçesinde hazırlanan yöresel yiyeceklerden en çok adı geçen on iki tanesi seçilmiş ve reçeteleri düzenlenmiştir. Yöresel yemekler içinde, Ödemiş köfte ilçe ekonomisinde önemli bir yere sahiptir, 37 tane sadece Ödemiş köftesi satan işletme bulunmasını bunun kanıtı olarak görmek mümkündür. Bunun yanında 125 yıl önce üretilmeye başlanan Töngül pide, sadece Ödemiş'te üretilen tescilli bir ürün olması sebebiyle de ayrıca önem arz etmektedir. Ödemiş'in yöresel mutfağında, ilçe kültürü ile yoğrularak günümüze kadar ulaşan; ekmek dolması, keşkek, peksimet, saç pidesi, kabak sinkonta, otlu sini pidesi, nohut mayalı ekmek, peksimet avutması, heybeli çorba, patates galgıtması da diğer önemli gastronomik verilerdir. Yapılan araştırma sonucunda; Ödemiş köfte sunan işletme sayısının 37 olması ve Töngül pidenin tarihi özellik taşıyan fırınında sunulması nedeniyle ilçenin yiyecek sunumunun bu iki gastronomik ürün üzerine yoğunlaştığını düşündürmektedir. Yapılan internet 
araştırmasında da Ödemiş'in yöresel yemekleri içerisinde ilk iki sırada yer almaktadırlar. Diğer reçetesi sunulan yöresel özellikli ürünlerinde ilçede ön plana çıkarılması ile gastronomik çekiciliğin arttırılması mümkündür. Bu amaçla, bu yöresel yiyecekleri sunan, yöresel özellikli işletmelerin açılması ya da şu an yöresel yiyecek sunan işletmelere bu yiyecekleri de eklenmesi sağlanabilir. Yöreye yapılan turların işletmelere uğraması sağlanarak ilçenin gastronomi turizmi açısından yöresel çekiciliği arttırılabilir.

Yöresel yiyecekleri tüketim ürünü olarak sunmanın yanında, ziyaretçilerin üretim sürecine katılmasını da sağlayacak atölyelerin kurularak, çekim unsuru olarak sunulması mümkündür. Günlük turların yanında, yöresel özellikli evlerde konaklamalı turlar düzenlenmesi, yöresel yiyecekleri tatma, üretme, ürünlerin üretildiği tarlaları ziyaret etme gibi kırsal turizmin farklı unsurlarının bir araya getirilmesi yörede turistik hareketliliği arttıracaktır. Akpulat (2015)'ın araştırma sonuçlarında; Ödemiş halkının, Ödemiş'in kırsal turizm gelişiminin sağlanmasında yöresel yiyeceklerin kullanılmasına olumlu baktıkları ortaya çıkarılmaktadır. Yöre mutfağını kültürel bir değer olarak gördükleri, geliştirilmesi amacıyla mutfak atölyesi kurulması ve geleneksel yemek festivali düzenlenmesi konusunda yüksek katılım gösterdikleri görülmektedir. Akpulat (2015) gastronomi turizmi ile ilgili olarak ilk yapılması gerekenin yöresel yemeklerle ilgili araştırma yapılması; yöresel yemeklerin isimleri, malzemeleri ve yapılışları ortaya konmalıdır önerisini getirmektedir. Bu araştırma; Ödemiş'in en çok bilinen on iki yöresel yemeği belirlenerek, reçetelerinin ortaya çıkarıldığı ilk araştırma olması açısından önemlidir.

\section{KAYNAKLAR}

Akgöl, Y. (2012). Gastronomi Turizmi ve Türkiye'yi Ziyaret Eden Yabancı Turistlerin Gastronomi Deneyimlerinin Değerlendirilmesi, Yayımlanmamış yüksek lisans tezi, Mersin Üniversitesi Sosyal Bilimler Enstitüsü, Mersin.

Akpulat, N.A. (2015) Ödemiş'in Kırsal Turizm Arz Kaynakları Açısından Değerlendirilmesi ve Öneriler. Uluslararası Sosyal ve Ekonomik Bilimler Dergisi, International Journal of Social and Economic Sciences 5 (2): 84-91, 2015, ISSN: 1307-1149, E-ISSN: 2146-0086.

Aksoy, M. ve Sezgi, G. (2015). Gastronomi Turizmi ve Güneydoğu Anadolu Bölgesi Gastronomik Unsurlar1, Journal of Tourism and Gastronomy Studies, 3 (3): 79-89.

Alyakut, Ö. (2017). Gastronomi Turizmi, Edt: Sami Karacan. Turizm Okumaları I., Umuttepe Yayınları: Kocaeli-İzmit. s.106-161.

Alyakut, Ö., ve Polat Üzümcü, T., (2017). Gastronomi Turizmi Bağlamında Kandıra Beslenme Kültürü ve Unutulmaya Yüz Tutmuş Lezzetleri: Goncaaydın Köyü Örneği. Uluslararası Çoban Mustafa Paşa ve Kocaeli Tarihi-Kültürü Sempozyumu-IV (pp.1837-1861). Kocaeli.

Avcıkurt C., Sarığlan M., Girgin G. K. (2007) Yiyecek-İçecek Olgusuna Sosyolojik Bir Bakış 1. Ulusal Gastronomi Sempozyumu ve Sanatsal Etkinlikler, 2007 Antalya.

Berber, E., Bulut, T., Gül T. Ali Orhan (2013). İlk Kurşun'un Anıları. Ödemiş̧ Belediyesi Yıldız Kent Arşivi Yayını.

Cömert, M., ve Özkaya, F.D. (2014). Gastronomi Turizminde Türk Mutfağının Önemi. Journal of Tourism and Gastronomy Studies 2(2): 62-66. 
Çakır A. Çakır, G. Dursun S. ve Dursun B. (2010). Kırsal Turizmde Yenilenebilir Enerji Kaynaklarının Kullanılması: Poyralı Köyünde Uygulanabilirliği. Uluslararası II.Trakya Bölgesi Kalkınma ve Girişimcilik Sempozyumu 1-2 Ekim, İğneada, Kırklareli.

Çeken, H., Karadağ, L. ve Dalgın, T. (2007). Kırsal Kalkınmada Yeni Bir Yaklaşım Kırsal Turizm ve Türkiye'ye Yönelik Bir Çalışma, Artvin Çoruh Üniversitesi Orman Fakültesi Dergisi, 7(1): 1-14.

Deveci, B. Türkmen, S. ve Avcıkurt, C. (2013). Kırsal Turizm ile Gastronomi Turizmi İlişkisi:Bigadiç Örneği, International Journal of Social and Economic Sciences, 3 (2): 29-34.

Ege Yemekleri- Tereyağlı Kebap (Ödemiş Köftesi), https://www.youtube.com/watch?v=e9B1isQlPAk, E.T.:27.02.2020.

Göker, G. (2011). Destinasyon Çekicilik Unsuru Olarak Gastronomi Turizmi: Balıkesir İli Örneği. Yüksek Lisans Tezi, Balıkesir Üniversitesi Sosyal Bilimler Enstitüsü.

Hall, C. M., and Mitchell, R. (2005). Gastronomic tourism: Comparing food and wine tourism experiences. In M. Novelli (Ed.), Niche Tourism: contemporary issues, trends and cases (pp. 7388): Routledge.

Hall, M., and Mitchell, R. (2000). We are what we eat: Food, tourism and globalization. Tourism, Culture and Communication, 2(1) 29-37.

Hatice İçel (75). Görüşme. (16.02.2020).

Horng, J.S. and T. Chen-Tsang (2012). Culinary Tourism Strategic Development: An Asia-Pacific Perspective, International Tourism of Journal Research, 14, 40-55.

http://www.odemisto.org.tr/Portals/290/2016/2018\%20EKONOM\%C4\%B0K\%20RAPOR.pdf E. T: 26.02.2020.

http://odemisliyiz.com/odemis-mutfagi/keskek/ ET: 26.02.2020.

http://www.nurmutfagi.de/odemis-koftesi-nasil-yapilir-tarifi-odemis-yagli-ekmekarasi-kofte- tarifi. ET: 26.02.2020.

http://www.odemisto.org.tr/Portals/290/2016/2018\%20EKONOM\%C4\%B0K\%20RAPOR.pdf E. T: 26.02.2020.

https://lezzetler.com/kabak-sinkonta-izmir- vt49476. ET: 26.02.2020.

https://www.facebook.com/harmandaliodemis/photos/a.867849576568506/867849566568507/?ty pe=3\&theater ET: 26.02.2020.

https://www.nefisyemektarifleri.com/nohut-mayali-odemis-ekmegi/).

https://www.yeniasir.com.tr/yasam/2019/06/27/izmir-odemisin-yoresel-lezzetleri-sinirlariasiyor?paging=5 ET: 26.02 .2020 .

https://www.youtube.com/watch?v=e9B1isQ1PAk ET: 26.02.2020.

Hu, Y., and Ritchie J. (1993). Measuring Destination Attractiveness: A Contextual Approach. Journal of Travel Research, 32(2): 25-34.

Kaşlı, M., Cankül, D., Köz, E.N. ve Ekici, A. (2015). Gastronomik Miras ve Sürdürülebilirlik: Eskişehir Örneği, Eko-Gastronomi Dergisi, 1(2), 27-46.

Kivela, J. and Crotts, J. C. (2006). Tourism and Gastronomy: Gastronomy's Influence on How Tourists Experience A Destination. Journal of Hospitality and Tourism Research, 30(3), 354-377. 
Kodaş, D. ve Dikici E. (2012). Ahlat, Kırsal Bölgesinde Gastronomi Turizminin Muhtemel Toplumsal Etkileri Üzerine Nitel Bir Çalışma, Aksaray Üniversitesi İiBF Dergisi, 4(2): 58-61.

Mil, B. (2009). Yemek Pişirmeden Gastronomiye Uzanan Bakış Açısıyla Küreselleşen Dünya, 3. Ulusal Gastronomi Sempozyumu, 17-18 Nisan 2009, Antalya.

Moira, P., Mylonopoulos, D. and Kontoudaki, A. (2015). Gastronomy as a form of cultural tourism a Greek typology, Tims.Acta: Naučni Časopis Za Sport, Turuzam Ivelnes, 9, 135-148.

Ongun, U. ve Gövdere, B. (2014). “Bölgesel Kalkınmada Kırsal Turizmin Etkisi: Ağlasun Yeşilbaşköy Örneği", Uluslararası Sosyal ve Ekonomik Bilimler Dergisi (IJSES), 4 (2): 51-57.

Özkaya, F.ve Can (2012). Gastronomi Turizminin Destinasyon Pazarlamasına Etkisi, Türk tarım, Gıda Tarım ve Hayvancılık Bakanlığı Dergisi, Temmuz-Ağustos, Sayı 206, s.28-33.

Polat Üzümcü, T. Alyakut Ö (2018). Gastronomi Turizmi Bağlamında Olur Mutfağının Geleneksel Yemekleri, Interanational Gastronomy Tourism Studies Congress, Kocaeli Üniversitesi, 20-22 112018.

Serçeoğlu, N. (2014). Yöre Halkının Mutfak Kültürünü Tanıma Durumunun Tespit Edilmesi: Erzurum İli Örneği, Journal of Tourism and Gastronomy Studies, 2(4): 36-46.

Soykan, F. (2003) Kırsal Turizm ve Türkiye Turizmi İçin Önemi, Ege Coğrafya Dergisi, 12 (2003) $1-11$.

Soykan, F., (2000). Kırsal Turizm ve Avrupa'da Kazanılan Deneyim, Anatolia Turizm Araştırmaları Dergisi, 11, 21-33.

Sürücüoğlu, M. S., ve Özçelik, A., Ö, (2008). Türk Mutfak ve Beslenme Kültürünün Tarihsel Gelişimi". 38. İcanas Kongresi., 10-15 Eylül, 1289-1310. Ankara.

Şahin, Güzel G. ve Ünver G. (2015). Destinasyon Pazarlama Aracı Olarak “Gastronomi Turizmi": İstanbul'un Gastronomi Turizmi Potansiyeli Üzerine Bir Araştırma Journal of Tourism and Gastronomy Studies 3(2): 63-73.

Şerefoğlu, Coşkun (2009). Kalkınmada Kırsal Turizmin Rolü- 2007-2013 Yılları Arasında Ülkemizde Uygulanacak Olan Ipard Kırsal Kalkınma Programındaki Yeri, Önemi ve Beklenen Gelişmeler. Tarım ve Köyişleri Bakanlığı Dış İlişkiler ve Avrupa Birliği Koordinasyon Dairesi Başkanlığı. Uzmanlık Tezi. Ankara.

Tez, Z. (2012). Lezzetin Tarihi. İstanbul: Hay kitap.

Uyar, H. ve Zengin, B. (2015). Gastronomi Turizminin Alternatif Turizm Çeşidi Olarak Değerlendirilmesi Bağlamında Gastronomi Turizm İndeksinin Oluşturulması, Akademik Sosyal Araştırmalar Dergisi, 17(3): 355-376.

Veer, M. and Tuunter, E. (2005). Rural Tourism in Europe. Hague.

Yüncü, H. (2010). Sürdürülebilir Turizm Açısından Gastronomi Turizmi ve Perşembe Yaylası. 10. Aybastı- Kabataş kurultayı: Yerel değerler ve yayla turizmi içinde (s. 28-34). Şengel, S. (Edt.) Detay Anatolia Akademik Yayıncllık, Ankara. 